\title{
Acute pancreatitis as a precursor sign of parathyroid adenoma
}

\author{
Paratiroid adenomun öncü belirtisi olarak akut pankreatit
}

\author{
Melek Uyar, ${ }^{1}$ M. Haluk Özkul, ${ }^{1}$ Özlem Bayram, ${ }^{1}$ Burak Dikmen, ${ }^{1}$ Songül Peltek Özer ${ }^{2}$ \\ ${ }^{1}$ Department of Otolaryngology, Haseki Training and Research Hospital, İstanbul, Turkey \\ ${ }^{2}$ Department of Pathology, Haseki Training and Research Hospital, İstanbul, Turkey
}

\begin{abstract}
In this article, we present a very rare case of acute pancreatitis caused by parathyroid adenoma-induced primary hyperparathyroidism (PHPT). A 27-year-old male was admitted to our hospital with severe abdominal pain, nausea and vomiting. He was under follow-up in the emergency room with the diagnosis of pancreatitis and symptoms associated with hypercalcemia. Biochemical findings suggested PHPT. Scintigraphy showed an increased focal activity under the left lobe of the thyroid gland. The patient underwent minimal invasive parathyroidectomy with preliminary diagnosis of parathyroid adenoma. Histopathological examination confirmed the diagnosis of parathyroid adenoma. The patient had normal serum calcium levels during the clinical followup. No recurrence or related complications were reported during one-year follow-up. Clinical improvement was provided by minimal invasive parathyroidectomy in our case. The relationship between acute pancreatitis and parathyroid adenoma should be kept in mind in the differential diagnosis in patients with non-biliar, non-alcoholic acute pancreatitis.
\end{abstract}

Keywords: Acute pancreatitis; hypercalcemia; parathyroid adenoma; primary hyperparathyroidism.

Primary hyperparathyroidism (PHPT) is a rare cause of acute pancreatitis. Elevated serum calcium levels may be responsible for the development of pancreatitis in patients with PHPT. Cause and effect relationship between two entities is not fully clear. In this article, an unfrequently case with acute pancreatitis as the first manifestation of parathyroid adenoma was presented. ${ }^{[1]}$

\begin{abstract}
$\ddot{O} Z$
Bu yazıda, paratiroid adenoma bağlı primer hiperparatiroidinin (PHPT) yol açtığı oldukça nadir bir akut pankreatit olgusu sunuldu. Yirmi yedi yaşında erkek hasta şiddetli karın ağrısı, bulantı ve kusma ile hastanemize başvurdu. Hasta hiperkalsemi ile ilişkili semptomlar ve pankreatit tanısı ile acil serviste takip edilmekte idi. Biyokimyasal bulgular PHPT'yi destekliyordu. Sintigrafide tiroid bezinin sol lob altında artmış fokal aktivite saptandı. Hastaya paratiroid adenom ön tanısı ile minimal invasiv paratiroidektomi yapıldı. Histopatolojik incelemede paratiroid adenom tanısı doğrulandı. Hastanın klinik takiplerinde serum kalsiyum düzeyleri normaldi. Bir yıllık takip sürecinde nüks veya ilişkili komplikasyon gözlenmedi. Olgumuzda minimal invaziv paratiroidektomi ile klinik iyileşme sağlandı. Nonbiliyer, nonalkolik akut pankreatitli hastalarda, akut pankreatit ve paratiroid adenom arasındaki ilişki ayırıcı tanıda düşünülmelidir.
\end{abstract}

Anahtar sözcükler: Akut pankreatit; hiperkalsemi; paratiroid adenom; primer hiperparatiroidizm. 


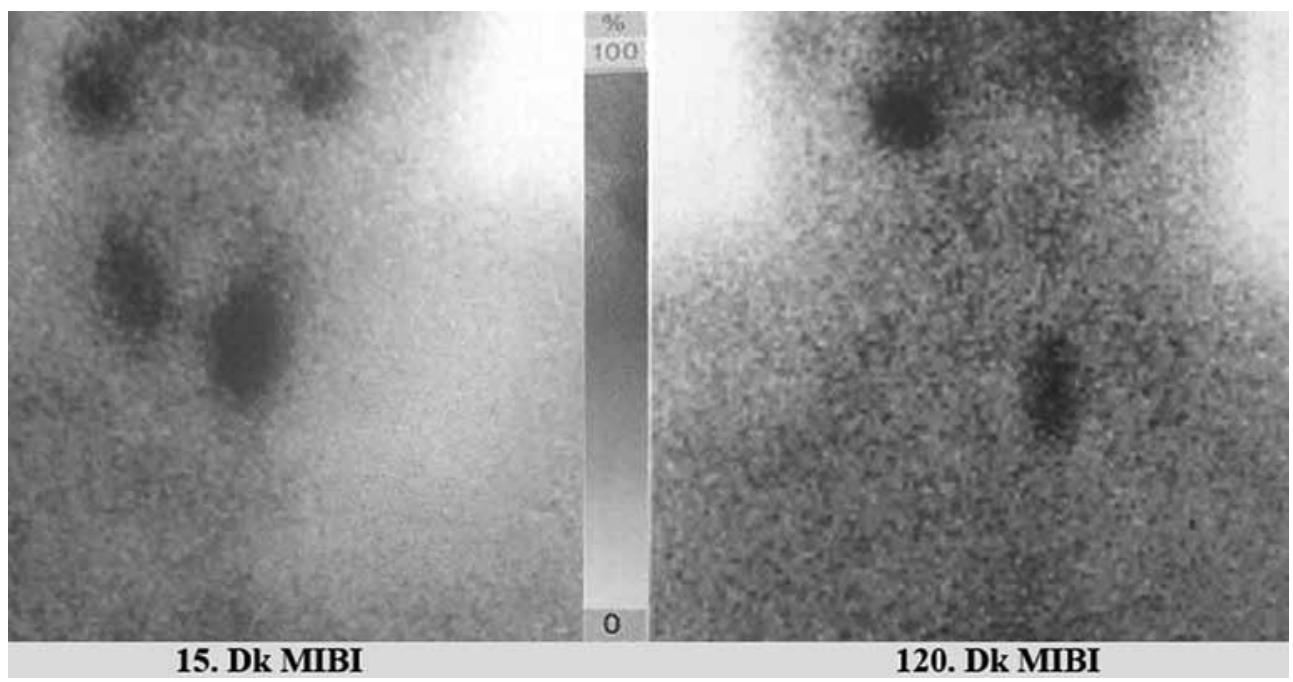

Figure 1. Technetium-99m-MIBI scintigraphy with early and two-hour delayed images of a left inferior parathyroid adenoma located inferior and in the same plane as the lower pole of the left thyroid gland.

no history of smoking, alcohol or drug use. Clinical examination was normal except for abdominal tenderness. Biochemical parameters of the patient were as follows: amylase $668.3 \mathrm{U} / \mathrm{L}$, white blood cell (WBC): 20 300/uL, C-reactive protein (CRP): 14.96, hemoglobin ( $\mathrm{Hb}): 14.4 \mathrm{~g} / \mathrm{dL}$, serum calcium level: $13.5 \mathrm{mg} / \mathrm{dL}$. Liver enzymes and albumin values were also normal. Aspartate aminotransferase (AST), alanine aminotransferase (ALT) and bilirubin were within normal limits. Abdominal ultrasound (USG) examination showed the edema of the pancreatic tissue. Cholecystitis, cholelithiasis and bile duct enlargement were not observed by USG. Abdominal computed tomography (CT) showed some findings relevant to non-biliary pancreatitis. The patient was diagnosed with acute pancreatitis due to hypercalcemia based on clinical, biochemical and radiological signs.

Consultation was requested for the differential diagnosis of hypercalcemia. Hypercalcemia was treated by hydration and diuretics. Primary hyperparathyroidism was thought to be in the etiology of pancreatitis considering to patient's age, history of nephrolithiasis, and also a sign of hypercalcemia. Some additional tests were performed for the differential diagnosis. Serum intact parathormon (PTH) level was $140 \mathrm{pg} / \mathrm{mL}$, $\mathrm{P}$ was $1.9,25-$ Hidroksi Vitamin $\mathrm{D}(25-\mathrm{OH}$ vit $\mathrm{D})$ was 35 . to $75 \mathrm{nmol} / \mathrm{L}$, and 24 hour urine calcium level was $440.4 \mathrm{mg} /$ day. There were no pathologic signs with the neck USG. A 9-mm nodule which was isointense with thyroid parenchyma and linear thin hypointense halo around was detected in $\mathrm{T}_{1 \mathrm{~A}}-\mathrm{T}_{2 \mathrm{~A}}$ series of the magnetic resonance imaging (MRI). It was located in the posteroinferior region of the left thyroid lobe. There was also an increased focal activity suggesting parathyroid adenoma in the same region by Technetium-99m-MIBI scintigraphy with single photon emission computed tomography (SPECT) images (Figure 1). Based on these results, minimally invasive parathyroidectomy was scheduled for the diagnosis of parathyroid adenoma and treatment of hypercalcemia. During surgical exploration of the neck, a nodule was found in the location, as described and it was removed (Figure 2). Parathyroid adenoma was confirmed with frozen-section analysis in the pathology department. Postoperative calcium and PTH levels returned to normal limits following

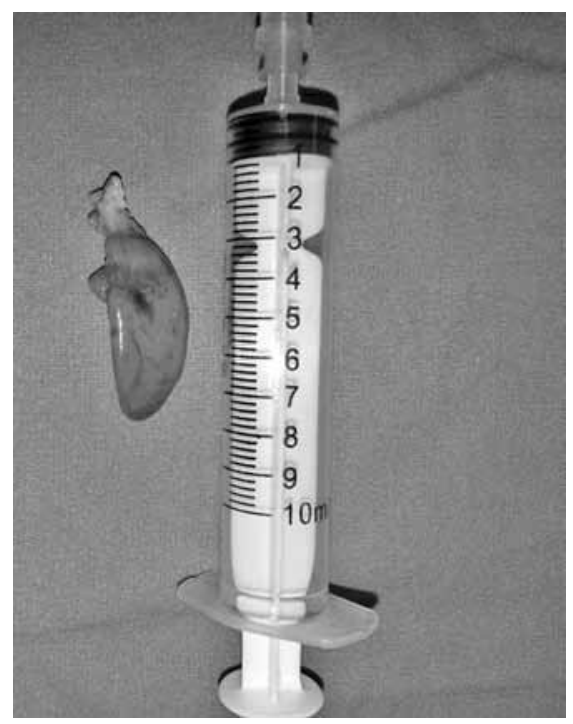

Figure 2. Macroscopic appearance of parathyroid pathology removed from the patient. 
surgery. Serum calcium was $8.6 \mathrm{mg} / \mathrm{dL}$. Intact PTH level was $27.9 \mathrm{pg} / \mathrm{mL}$. The patient was discharged one day after surgery. In the pathological examination, it was $1.5 \times 1 \times 1 \mathrm{~cm}$ with tan to reddish-brown color and soft material with a thin capsule. There was a yellowishbrown rim of glandular normal tissue. Mitosis was absent. There was a rim of compressed non-neoplastic parathyroid tissue. As a result of this assessment, it was reported as parathyroid adenoma (Figure3). No recurrence or related complications were encountered during one-year follow-up period.

\section{DISCUSSION}

A postmortem case of pancreatitis with PHPT was documented for the first time in $1903 .{ }^{[2]}$ Pancreatitis as a feature of PHPT has become well known after an article published in the journal of The Annals of Surgery in $1957 .{ }^{[3]}$ The actual causal relationship between hypercalcemia and pancreatitis has been a persistent topic of debate, although there are many cases in the literature. In this article, we report a 27-year-old man with acute pancreatitis secondary to PHPT-induced parathyroid adenoma.

The incidence of pancreatitis risk is known to be 10 fold elevated in PHPT. ${ }^{[4]}$ Biliary stones and alcohol are common causes of acute pancreatitis. Hypertriglyceridemia or hyperglycemia are responsible of acute pancreatitis to varying degrees. ${ }^{[5]}$ In our case, the patient had no history of cholecystitis with biliary stones or any alcohol ingestion and his AST, ALT, and bilirubin were within normal limits.

Hypercalcemia is one of the rare causes of acute pancreatitis and ectopic activation of trypsinogen

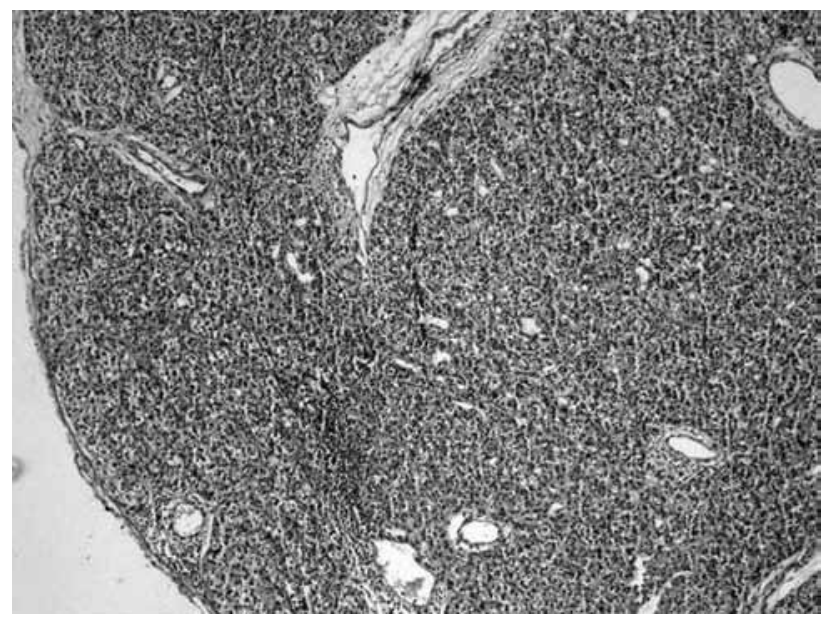

Figure 3. Postoperative pathology of the parathyroid adenoma (non-neoplastic parathyroid tissue, mitoses was absent) consisting mainly of chief cells with occasional groups of oxyphil cells and water clear cells ( H-E x 100). to trypsin and induced formation of pancreatic calculus. $^{[3,4,6]}$ Hypocalcemia is expected during an attack of pancreatitis and hypercalcemia may be a clue for the diagnosis of PHPT. ${ }^{[7,8]}$ Therefore, the presence of hypercalcemia in acute pancreatitis should be investigated such as malignancy or hyperparathyroidism. In our case, there was no clear etiological agent for pancreatitis expect hypercalcemia.

Primary hyperparathyroidism-induced pancreatitis occurs most likely through hypercalcemia. The other conditions of hypercalcemia, such a metastatic bone disease, total parenteral nutrition, sarcoidosis, vitamin $\mathrm{D}$ toxicity, and infusions of calcium also may cause pancreatitis. ${ }^{[9]}$ The persistent hypercalcemia may lead to increased calcium concentrations in pancreatic juice and calcium activation of trypsinogen within pancreatic parenchyma and disruptions acinar cell. ${ }^{[9-11]}$ Long-standing hypercalcemia may also decrease the volume of pancreatic juice and cause protein plugs leading to an obstruction in the pancreatic duct. ${ }^{[12]}$ Some authors have described that PTH may act itself and cause local thrombo-endarteritis and necrosis of pancreatic tissue. ${ }^{[7,13]}$ The other association between PHPT and pancreatitis is that serum calcium levels decrease to normal values and healing on clinical finding of pancreatitis is present following surgery. The most common cause of PHPT is a single adenoma of the parathyroid gland. ${ }^{[14]}$ The other causes include parathyroid hyperplasia, carcinoma, multiple endocrine neoplasia, or parathyroid cysts. ${ }^{[5]}$ In our case, we present a single parathyroid adenoma as a cause of PHPT.

Acute pancreatitis is a wide variation in clinical features and severity, ranging from mild and self-limited to a rapidly progressive illness leading to multiple organ failure and death. Therefore, the definite diagnosis of acute pancreatitis can be challenging. It is a potentially fatal disease with an overall mortality of $2.1-7.8 \% .{ }^{[15]}$ Autopsy studies showed that acute pancreatitis more frequently encountered in postmortem cases than alive. ${ }^{[16]}$ On the other hand, forty-six percent of the patients who had a recurrence experienced it within one year of the initial attack. ${ }^{[14]}$ Hence, our patient had a preliminary diagnosis of acute pancreatitis with PHPT. Minimal invasive parathyroidectomy was sufficient for both the diagnosis and treatment. Our patient fully recovered in a short time of period of hospitalization by minimal invasive surgery. No recurrence or related complications were observed during one-year follow-up.

In conclusion, treatment of acute pancreatitis should be targeted for the reason. In the differential diagnosis of acute pancreatitis due to hypercalcemia-induced primary hyperparathyroidism (PHPT), parathyroid adenoma 
should be considered to enable clinical improvement and prevent relapses.

\section{Declaration of conflicting interests}

The authors declared no conflicts of interest with respect to the authorship and/or publication of this article.

\section{Funding}

The authors received no financial support for the research and/or authorship of this article.

\section{REFERENCES}

1. Chowdhury SD, Kurien RT, Pal S, Jeyaraj V, Joseph AJ, DuttaAK, etal. Acute pancreatitis and hyperparathyroidism: a case series. Indian J Gastroenterol 2014;33:175-7.

2. Kelly TR. Relationship of hyperparathyroidism to pancreatitis. Arch Surg 1968;97:267-74.

3. Cope O, Culver PJ, Mixter CG Jr, Nardi GL. Pancreatitis, a diagnostic clue to hyperparathyroidism. Ann Surg 1957;145:857-63.

4. Akce M, Wasco M, Kimball B, Saberi S. Acute Pancreatitis as the first manifestation of parathyroid adenoma. J Endocrinol Metab 2012;2:187-9.

5. Bai HX, Giefer M, Patel M, Orabi AI, Husain SZ. The association of primary hyperparathyroidism with pancreatitis. J Clin Gastroenterol 2012;46:656-61.

6. Frick TW, Fernández-del Castillo C, Bimmler D, Warshaw AL. Elevated calcium and activation of trypsinogen in rat pancreatic acini. Gut 1997;41:339-43.

7. Smith MD, Pawlak M, Pantanowitz DP, Botha RJ.
Hyperparathyroidism and chronic pancreatitis. S Afr J Surg 1999;37:12-4.

8. Nikolaidis LA, Leon MN, Paslidis NJ. Acute pancreatitis as the first manifestation of hyperparathyroidism in an otherwise asymptomatic patient. J Ark Med Soc 1995;92:273-5.

9. Frick TW. The role of calcium in acute pancreatitis. Surgery 2012;152:S157-63.

10. Egea Valenzuela J, Belchí Segura E, Sánchez Torres A, Carballo Alvarez F. Acute pancreatitis associated with hypercalcemia. A report of two cases. Rev Esp Enferm Dig 2009;101:65-9.

11. Fraser WD. Hyperparathyroidism. Lancet 2009;374:14558.

12. Cho JW, Seligson U, Somell A. Pancreatic function in patients with hyperparathyroidism. A study with the Lundh test. Acta Chir Scand 1985;151:323-5.

13. Boneschi M, Erba M, Beretta L, Miani S, Bortolani EM. Primary hyperparathyroidism and acute pancreatitis. A rare clinical association. Minerva Chir 1999;54:451-4. [Abstract]

14. Williams BA, Trites JR, Taylor SM, Bullock MJ, Hart RD. Surgical management of primary hyperparathyroidism in Canada. J Otolaryngol Head Neck Surg 2014;43:44.

15. Sekimoto M, Takada T, Kawarada Y, Hirata K, Mayumi T, Yoshida M, et al. JPN Guidelines for the management of acute pancreatitis: epidemiology, etiology, natural history, and outcome predictors in acute pancreatitis. J Hepatobiliary Pancreat Surg 2006;13:10-24.

16. Dervenis C, Johnson CD, Bassi C, Bradley E, Imrie CW, McMahon MJ, et al. Diagnosis, objective assessment of severity, and management of acute pancreatitis. Int J Pancreatol 1999;25:195-210. 